\title{
Response of Sowing Dates and Fertilizer Levels on Growth, Yield and Quality of Sesamum (Sesamum Indicum L.)
}

\author{
S.R. Muneshwar*, G.M. Kote and V.B. Awasarmal \\ Department of Agronomy, Vasantrao Naik Marathwada Krishi Vidyapeeth, \\ Parbhani (MS), India \\ *Corresponding author
}

\section{A B S T R A C T}

\section{Keywords}

Sowing dates, Fertilizer levels, Sesamum

\section{Article Info}

Accepted:

12 October 2019

Available Online:

10 November 2019
A field experiment was conducted at Instructional farm, Department of Agronomy, COA, Parbhani on a clayey soil during kharif season of 2018 to find out the effect of with two factors viz., sowing dates [four levels: $\mathrm{D}_{1}\left(15^{\text {th }}\right.$ June $), \mathrm{D}_{2}\left(30^{\text {th }}\right.$ June $), \mathrm{D}_{3}\left(15^{\text {th }} \mathrm{July}\right)$ and $\mathrm{D}_{4}\left(30^{\text {th }}\right.$ July $\left.)\right]$ and three fertilizer levels $\left[F_{1}(75 \% \mathrm{RDF}), \mathrm{F}_{2}(100 \% \mathrm{RDF})\right.$ and $\left.\mathrm{F}_{3}(125 \% \mathrm{RDF})\right]$ with twelve treatments combinations. Each experimental unit was repeated three times. The fertilizer dose of 50:25:00 NPK kg ha ${ }^{-1}$ was applied after sowing. Amongst sowing dates, Crop sown on $15^{\text {th }}$ June recorded significantly higher growth attributes, yield attributes, seed yield (435 kg ha $\left.{ }^{-1}\right)$, straw yield $\left(1541 \mathrm{~kg} \mathrm{ha}^{-1}\right)$, biological yield $\left(1975 \mathrm{~kg} \mathrm{ha}^{-1}\right)$. Amongst fertilizer levels, $125 \% \mathrm{RDF}\left(\mathrm{F}_{3}\right)$ recorded significantly higher growth attributes, yield attributes, seed yield (375 $\left.\mathrm{kg} \mathrm{ha}^{-1}\right)$, straw yield $\left(1381 \mathrm{~kg} \mathrm{ha}^{-1}\right)$, biological yield $\left(1756 \mathrm{~kg} \mathrm{ha}^{-1}\right)$, harvest index $(21.36 \%)$. From result it can be concluded that, sowing of sesamum on $15^{\text {th }}$ June and $30^{\text {th }}$ June was found beneficial as compared to other sowing dates. Among the various fertilizer levels the application of fertilizer level $100 \%$ RDF was more profitable.

\section{Introduction}

Sesamum (Sesamum indicum L.) which is known variously as sesamum, til, gingelly, simsim, gergelim etc. is one of the most important oil seed crop grown extensively in India. Sesamum is the oldest indigenous oil plant with longest history of its cultivation in
India. Africa has been considered as the center of origin of this crop (Joshi, 1961). It belongs to order Tubiflorae and family Pedaliaceae. Sesamum is having quality food, nutrition, edible oil, biomedicine and health care, all in one. Sesamum has remarkable antioxidant function due to the presence of lignin and tocopherol. The seed is highly rich in quality 
protein and essential amino acid especially methionine is considered rejuvenate and antiadding for human body.

Sowing time of sesame play an important role on its average production for different agroclimatic region which is mostly grown under rain fed conditions. Thus, the rainfall pattern (onset and termination of rainfall and distribution of rainfall) influence the growth and yield of crop. The late onset of monsoon generally delays the sowing resulting in to poor yield. This necessitates finding out suitable sowing time with the consideration to the effect of temperature on plant. Degree days concept based on the idea that plants have a specific temperature requirement for the completion of particular physiological stage will definitely provide ample scope to find the suitability of sowing time.

Fertilizer is one of the most important inputs for successful crop production. A sustainable increase in production can be obtained by using balanced fertilizers. More scientific efforts are needed to increase the productivity of sesamum per unit area and per unit time with soil moisture conservation and optimum fertilizer dose. Therefore, it is necessary to study the behavior of sesamum under various fertilizer levels. The major plant nutrients applied through chemical fertilizers may not be taken up properly by plant roots of crop plants due to poor organic carbon content and water holding capacity of soil. The variability in crop performance arising from different sowing dates is a consequence of changes in the factors of environment in time. This study is therefore carried out to determine the optimum time of sowing and to identify suitable fertilizer levels.

\section{Materials and Methods}

A field experiment was conducted during the period of 2018-19 at Experimental Farm of
Agronomy at College of Agriculture, Parbhani. The soil was clayey in texture, low in available nitrogen $\left(231 \mathrm{~kg} \mathrm{ha}^{-1}\right)$, low in available phosphorus $\left(12.64 \mathrm{~kg} \mathrm{ha}^{-1}\right)$, rich in available potash (474 $\left.\mathrm{kg} \mathrm{ha}^{-1}\right)$, sulphur (15.25 $\mathrm{kg} \mathrm{ha}^{-1}$ ) and slightly alkaline in reaction. The soil was moderately alkaline in reaction (8.13 $\mathrm{pH})$. In general, weather conditions were favorable for plant growth and no severe pest and diseases noticed during experimentation. The study involved twelve treatment combinations consisting two factors viz., sowing dates [four levels: $\mathrm{D}_{1}\left(15^{\text {th }}\right.$ June $), \mathrm{D}_{2}$ ( $30^{\text {th }}$ June $), \mathrm{D}_{3}\left(15^{\text {th }}\right.$ July) and $\mathrm{D}_{4}\left(30^{\text {th }}\right.$ July $\left.)\right]$ and three fertilizer levels $\left[\mathrm{F}_{1}(75 \% \mathrm{RDF}), \mathrm{F}_{2}\right.$ $\left(100 \%\right.$ RDF) and $\left.\mathrm{F}_{3}(125 \% \mathrm{RDF})\right]$ with twelve treatments combinations in split plot design with three replications. The Each experimental unit was repeated three times $5.40 \mathrm{~m} \mathrm{x} 4.5 \mathrm{~m}^{2}$ size in gross plot and in net plot $4.5 \times 4.0 \mathrm{~m}^{2}$.

Sowing was completed as per treatments. The fertilizer dose of 50:25:00 NPK kg ha ${ }^{-1}$ was applied after sowing. The package of recommended practices was adopted to maintain the crop.

\section{Results and Discussion}

\section{Effects on growth attributes}

\section{Sowing dates}

Plant height, number of branches, mean total dry matter plant ${ }^{-1}$, and number of capsules per plant were significantly influenced due to sowing dates.

Amongst the sowing dates, crop sown on $15^{\text {th }}$ June recorded maximum Plant height, number of branches, mean total dry matter plant ${ }^{-1}$, and number of capsules per plant at all growth stages, followed by $15^{\text {th }}$ and $30^{\text {th }}$ July, respectively. The better performance of $15^{\text {th }}$ June may be attributed to its better vegetative growth over $15^{\text {th }}$ and $30^{\text {th }}$ July, respectively. 


\section{Fertilizer levels}

Fertilizer levels significantly influenced all the growth attributes viz., Plant height, number of branches, mean total dry matter plant ${ }^{-1}$, and number of capsules per plant at harvest.

The application of $125 \%$ RDF recorded more number of branches and dry matter accumulation $\left(\mathrm{cm}^{2}\right)$ which was found at par with the application of $100 \%$ RDF.

The significantly lowest number of branches, dry matter production and number of capsules were recorded by application of $75 \% \mathrm{RDF}$ at all stages of the crop growth. Application of $125 \%$ RDF was found significantly effective over $100 \% \mathrm{RDF}$ and $75 \% \mathrm{RDF}$ in increasing growth attribute of sesamum. Similar results were found by Rao et al., (1993), Paramasivam et al., (2003), Barik and Fulimali (2011) and Tripathy and Bastia (2012).

\section{Effect on Yield attributes and yield}

\section{Sowing dates}

Various yield attributes viz., number of capsuls plant ${ }^{-1}$, weight of capsuls plant ${ }^{-1}$, weight seed yield plant ${ }^{-1}$ and test weight were significantly influenced due to four sowing dates under study, except number of seeds per pod which was not significantly influenced due to varieties. Crop sown on $15^{\text {th }}$ June recorded significantly maximum number of capsules plant ${ }^{-1}$, weight of capsules plant ${ }^{-1}$, weight seed yield plant ${ }^{-1}$ and test weight than $15^{\text {th }}$ and $30^{\text {th }}$ July, respectively. The data showed that the sowing date of $15^{\text {th }}$ June $\left(\mathrm{D}_{1}\right)$ recorded significantly higher seed yield (435 $\mathrm{kg} \mathrm{ha}^{-1}$ ) than crop sown on $15^{\text {th }}$ and $30^{\text {th }}$ July, but it was found at par with the sowing date of $30^{\text {th }}$ June $\left(\mathrm{D}_{2}\right)\left(405 \mathrm{~kg} \mathrm{ha}^{-1}\right)$.

\section{Fertilizer levels}

The application of $125 \% \mathrm{RDF}$ and $100 \%$ RDF produced significantly higher number of capsuls plant ${ }^{-1}$, weight of capsuls plant ${ }^{-1}$, weight seed yield plant ${ }^{-1}$ and test weight than $75 \%$ RDF. The application of $75 \%$ RDF recorded significantly lowest number of branches plant ${ }^{-1}(1.55)$, than fertilizer levels.

The application of $125 \%$ RDF recorded significantly higher seed yield $\left(375 \mathrm{~kg} \mathrm{ha}^{-1}\right)$ which was found at par with the application of $100 \%$ RDF (356 kg ha $\left.{ }^{-1}\right)$. Application of $75 \%$ RDF (312 kg ha-1) recorded significantly lowest seed yield. Such type of results are found by Deshmukh et al., (2002), Haruna (2011), Sawant et al., (2013) and Kashani et al., (2015).

\section{Effect on quality}

\section{Sowing dates}

Results revealed (Table 1) that different sowing dates did not show their significant influence on oil content $(\%)$ in the seeds. However, oil yield (Table 2) was significantly influenced due to different sowing dates. Significantly higher oil yield $\left(215.64 \mathrm{~kg} \mathrm{ha}^{-1}\right)$ was observed under sowing date of $15^{\text {th }}$ June $\left(D_{1}\right)$ and it was found at par with sowing date of $30^{\text {th }}$ June $\left(D_{2}\right)\left(198.75 \mathrm{~kg} \mathrm{ha}^{-1}\right)$. Similar results were reported by Amanullah et al., (2014), Mshelia et al., (2014) and Patel et al., (2010).

\section{Fertilizer levels}

The significantly highest oil yield $(182.30 \mathrm{~kg}$ $\mathrm{ha}^{-1}$ ) was observed under application of $125 \%$ RDF, while the significantly lowest oil yield $\left(151.81 \mathrm{~kg} \mathrm{ha}^{-1)}\right.$ was registered under the treatment of $75 \%$ RDF. 
Table.1 Growth and yield attributes of sesamum at harvest as influenced by various sowing dates and fertilizer levels

\begin{tabular}{|c|c|c|c|c|c|c|c|}
\hline Treatments & $\begin{array}{c}\text { Plant } \\
\text { height } \\
\text { (cm) }\end{array}$ & $\begin{array}{c}\text { Number of } \\
\text { branches } \\
\text { plant }^{-1}\end{array}$ & $\begin{array}{l}\text { Dry matter } \\
\text { production } \\
\left(\text { g plant }^{-1}\right)\end{array}$ & $\begin{array}{c}\text { Number of } \\
\text { capsuls }^{-1} \\
\text { plant }^{-1}\end{array}$ & $\begin{array}{l}\text { Weight of } \\
\text { capsule } \\
\text { plant }^{-1}(g)\end{array}$ & $\begin{array}{l}\text { Wt. of seed } \\
\text { plant }^{-1} \\
(\text { gm) }\end{array}$ & $\begin{array}{c}\text { Test weight } \\
\text { (gm) }\end{array}$ \\
\hline \multicolumn{8}{|l|}{ Sowing dates (04) } \\
\hline$D_{1}\left(15^{\text {th }}\right.$ June $)$ & 115.44 & 3.91 & 22.05 & 26.11 & 7.62 & 2.52 & 2.92 \\
\hline$D_{2}\left(30^{\text {th }}\right.$ June $)$ & 108.88 & 3.60 & 19.44 & 24.22 & 7.22 & 2.20 & 2.81 \\
\hline$D_{3}\left(15^{\text {th }}\right.$ July $)$ & 98.00 & 3.28 & 15.05 & 20.00 & 6.51 & 1.76 & 2.71 \\
\hline$D_{4}\left(30^{\text {th }}\right.$ July $)$ & 90.00 & 2.78 & 12.66 & 17.33 & 5.59 & 1.38 & 2.62 \\
\hline $\mathrm{SE} \pm$ & 2.28 & 0.094 & 0.76 & 0.64 & 0.19 & 0.10 & 0.17 \\
\hline CD at $\overline{5 \%}$ & 7.89 & 0.326 & 2.62 & 2.21 & 0.67 & 0.35 & NS \\
\hline \multicolumn{8}{|l|}{ fertilizer levels (03) } \\
\hline $\mathrm{F}_{1}(\mathbf{7 5 \%} \mathrm{RDF})$ & 94.00 & 3.05 & 14.20 & 19.67 & 6.30 & 1.61 & 2.54 \\
\hline $\mathrm{F}_{2}(100 \% \mathrm{RDF})$ & 104.66 & 3.49 & 17.83 & 22.16 & 6.84 & 2.06 & 2.80 \\
\hline $\mathrm{F}_{3}(125 \% \mathrm{RDF})$ & 110.58 & 3.68 & 19.87 & 23.91 & 7.06 & 2.22 & 2.95 \\
\hline $\mathrm{SE}_{ \pm}$ & 2.44 & 0.102 & 0.72 & 0.65 & 0.16 & 0.08 & 0.12 \\
\hline CD at $5 \%$ & 7.32 & 0.305 & 2.16 & 1.95 & 0.49 & 0.22 & NS \\
\hline \multicolumn{8}{|l|}{ Interaction } \\
\hline $\mathrm{SE} \pm$ & 4.88 & 0.203 & 1.44 & 1.29 & 0.33 & 0.14 & 0.24 \\
\hline CD at $5 \%$ & NS & NS & NS & NS & NS & NS & NS \\
\hline General Mean & 103.08 & 3.40 & 17.30 & 21.91 & 6.73 & 1.96 & 2.76 \\
\hline
\end{tabular}


Table.2 Yield and quality of sesamum at harvest as influenced by various sowing dates and fertilizer levels

\begin{tabular}{|c|c|c|c|c|c|c|}
\hline Treatments & $\begin{array}{c}\text { Seed yield } \\
\left(\mathrm{kg} \mathrm{ha}^{-1}\right)\end{array}$ & $\begin{array}{l}\text { Straw yield } \\
\left(\mathrm{kg} \mathrm{ha}^{-1}\right)\end{array}$ & $\begin{array}{c}\text { Biological } \\
\text { yield } \\
\left(\mathrm{kg} \mathrm{ha}^{-1}\right)\end{array}$ & $\begin{array}{c}\text { Harvest Index } \\
(\%)\end{array}$ & Oil content $(\%)$ & $\begin{array}{l}\text { Protein content } \\
\qquad(\%)\end{array}$ \\
\hline \multicolumn{7}{|l|}{ Sowing dates } \\
\hline$D_{1}\left(15^{\text {th }}\right.$ June $)$ & 435 & 1541 & 1975 & 22.02 & 49.61 & 21.36 \\
\hline$D_{2}\left(30^{\text {th }}\right.$ June $)$ & 405 & 1468 & 1873 & 21.62 & 49.03 & 21.10 \\
\hline$D_{3}\left(15^{\text {th }} \mathrm{July}\right)$ & 312 & 1205 & 1517 & 20.56 & 47.63 & 20.54 \\
\hline$D_{4}\left(30^{\text {th }}\right.$ July $)$ & 239 & 961 & 1201 & 19.90 & 47.31 & 20.20 \\
\hline $\mathrm{SE} \pm$ & 11.69 & 38.79 & 44.22 & - & 0.51 & 0.25 \\
\hline CD at $\overline{5} \%$ & 40.47 & 134.24 & 153.02 & - & NS & NS \\
\hline \multicolumn{7}{|l|}{ Fertilizer levels } \\
\hline $\mathrm{F}_{1}(75 \% \mathrm{RDF})$ & 312 & 1181 & 1494 & 20.88 & 48.34 & 20.67 \\
\hline $\mathrm{F}_{2}(100 \% \mathrm{RDF})$ & 356 & 1319 & 1675 & 21.25 & 48.41 & 20.82 \\
\hline $\mathrm{F}_{3}(125 \% \mathrm{RDF})$ & 375 & 1381 & 1756 & 21.36 & 48.44 & 20.90 \\
\hline $\mathrm{SE}_{ \pm}$ & 8.08 & 43.02 & 43.72 & - & 0.44 & 0.22 \\
\hline CD at $5 \%$ & 24.23 & 128.97 & 131.09 & - & NS & NS \\
\hline Interaction (D X F) & & & & - & & \\
\hline $\mathrm{SE} \pm$ & 16.16 & 86.04 & 87.45 & - & 0.89 & 0.45 \\
\hline CD at $\overline{5} \%$ & 48.47 & NS & NS & - & NS & NS \\
\hline GM & 347.6 & 1293.80 & 1641.50 & - & 48.40 & 20.80 \\
\hline
\end{tabular}


Fertilizer level $125 \%$ RDF was found at par with $100 \%$ RDF. The significantly highest protein yield (78.86 kg ha-1) was observed under application of $125 \% \mathrm{RDF}$, while the significantly lowest oil yield $\left(65.15 \mathrm{~kg} \mathrm{ha}^{-1}\right)$ was registered under the treatment of $75 \%$ RDF. Similar results were reported by Thanki et al., (2004) and Tripathy and Bastia (2012).

\section{References}

Amanullah, Janand Shahzad Ali (2014). sowing dates and nitrogen level Effect on yield and yield attributes of sesame cultivars, sarhad J. Agric. Vol.30, NO. 2 .

Barik, A. K.and Fulimali, J., (2011). Effect of integrated plant nutrient supply through organic mineral sources on productivity of summer sesame. $J$ Oilseeds Res.,28 (2) 120-122

Deshmukh, M. R., Jain, H. C., Duhoon, S. S. and Goswami, U. (2002) Integrated nutrient management in sesame for Kymore plateau zone of Madhya Pradesh J. Oiseeds Res., 19 (1): 73-75

Haruna, I. M. (2011). Growth and Yield of Sesame (Sesamum indicum L.) as influenced by Nitrogen and intra row spacing in Lafia. Nasarawa State of Nigeria. Elixir Agriculture, 41:56855688.

Kashani, S. M. Buriro A. Nadeem, N. Ahmed, Saoed, F. Mohamad and S Ahemd (2015). Response of Various Sesame Varieties under the Influence of nitrogen and phosphorus doses. American J. Plnat Sci., 6: 405-412.

Mshelia, J. S., Sajo, A. A. and Gungula.D. T.
(2014). Effects of sowing date and intra- row spacing on oil, crude protein, crude fibre and ash contents of sesame (Sesamum indicum L.) seed in yola, Nigeria. I. J. S. N. 5 (2): 186-190.

Paramasivam, V., Ravichandran, V. K., Venkatesan, P. K. and Manoharan, V. (2003). Nutrient management for seed yield maximisation $\mathrm{n}$ sesame (Sesamum indicum L.). Sesame \& Safflower Newsletter No. 18.

Patel, G. K., Patel, I. C., Patel, D. M., Patel, G. N., (2010). Production potential of summer sesame varieties in relation to dates of sowing under north Gujarat agro-climatic conditions. $J$ oilseed Res., 27 (1): 74-75.

Rao, P V. and Raikhelkar, S. V. (1993). Effect of irrigation and fertilization on growth and yield in sesame. J, Oilseeds Res., 10: 31-36.

Sawant, V. B., V.V.Sonani, S.S. Raskar and P.A. Patil (2013). Effect of different levels of nitrogen, phosphorus and sulphur on yield and yield attribute of summer sesamum (Sesamum indicum L.). Int. J Current Res. X(5): 27442745.

Thanki, J. D., Patl, A. M. and Patel, M. P., (2004). Effect of dates of sowing, phosphorus and bio-fertilizer on growth, yield and quality of summer sesamum (Sesamum indicum L.). J. Oilseeds Res., 21(2): 301-302.

Tripathy, S and Bastia D K., (2012). Irrigation and nutrient management for yield augmentation of summer sesame (Sesamam indicum L.) J. Crop \& Weed, 8(2) 53-57.

\section{How to cite this article:}

Muneshwar, S.R., G.M. Kote and Awasarmal, V.B. 2019. Response of Sowing Dates and Fertilizer Levels on Growth, Yield and Quality of Sesamum (Sesamum Indicum L.). Int.J.Curr.Microbiol.App.Sci. 8(11): 1704-1709. doi: https://doi.org/10.20546/ijcmas.2019.811.198 